\title{
40 パルーンカテーテル加压器の圧カ計は正確か?
}

縄田昌浩, 田村俊世, 戸川達男（東京医科歯科大学医用器材研究所）

【はじめに】経皮的血管形成術用のバ ルーンカテーテル使用時には，適正な バルーン拡張を行うため, 圧力計を備 えた加圧器の使用が不可欠である。し かし, この加圧器の圧力計には, 経驗 的に大きな䛊差を有するものがある. バルーンに適正な圧力が作用しないと， バルーン破裂や拡張不十分などの合併 症をまねきかねない。そこで各社の加 圧器の圧力計誤差を計測し, 効果的な カテーテル治療へ反映することを目的 とした。

【対象】以下に示す 4 種類の製品を対 象とした。販売名はインディフレータ 一, ディスポーザブル P T C A キット など製品により異なるが，バルーンカ テーテル加圧用に承認された，シリン ジ先端部分に圧力計を備えた製品であ る. 全ての加圧器のシリンジの容量は $20 \mathrm{~m} 1$ である. また例数は各タイプ 1 個である。

1，ATM-25,アナログ表示， 最大圧力 $25 \mathrm{~atm}$, 日本ライフラ隹。

2, IP9001,アナログ表示, 最大圧力 20atm, B a $x \mathrm{t}$ e r

3, MX380,アナログ表示, 最大圧力 $20 \mathrm{~atm}, \mathrm{Me} \mathrm{d}$ e x .

4, Monarch25,デジタル表示, 最大圧力 25atm,シーマン.

【方法】4種類の加圧器から伸びる個 々のチューブ 4 本と, 基準となる圧力 計 (AU形, 最大压 $35 \mathrm{kgf} / \mathrm{cm}^{2}$, JIS 1.0 級 大東計器製作所) を, 一つ の閉鎖された回路で接続した（図 1 ）。
回路内は蒸留水を満たし, 気泡除去と 接続の確認のため, 加圧器のスクリュ 一を回し, 回路の圧力を一旦 $20 \mathrm{~atm}$ まで加圧した。 その後ふたたび $0 \mathrm{~atm}$ にもどし，基準となる圧力計の值を 2 〜 $18 \mathrm{~atm}$ まで徐々に上昇させ, 基準 の圧力 $1 \mathrm{~atm}$ ごとに, 各加圧器の圧力 計の示す值を読み取った。ここでは哖 床上便宜的に用いている atm を単位 系として使用いた. $1 \mathrm{~atm}=101.32 \mathrm{kPa}$ である。

パスカルの原理により，この閉鎖さ れた回路の一部に加えられた圧力は, その值を変えることなく全ての管壁に 等しく作用している。本来なら全ての 加圧器の圧力計は, 等しい俌を示すは ずである。計测值の誤差は以下のよう に算出した。

$$
\text { 證差 }=\frac{\text { 加圧器の圧力計俌 }- \text { 基準圧力 }}{\text { 基淮圧力 }}
$$

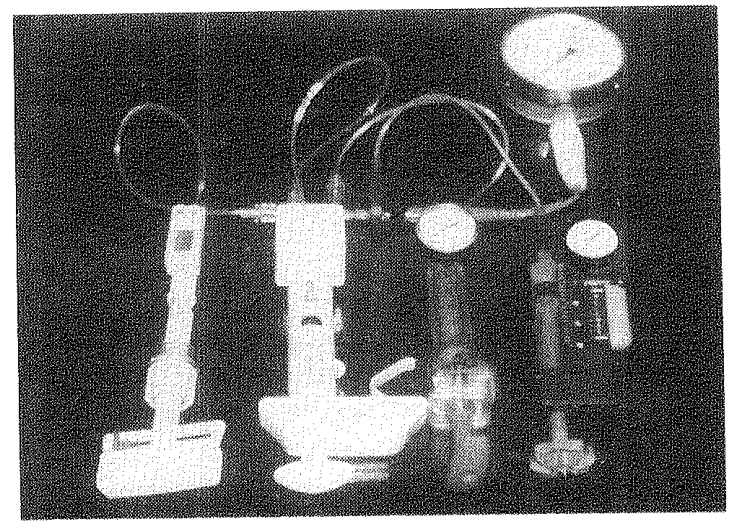

図 1 計測のための閉鎖回路 
【結果】基準の圧力に対する誤差を示 寸（図 2)。高い圧力の誤差は小さい が，実際に末梢血管拡張用バルーンで 使用寸る低い压力では，約 $10 \%$ の誤 差が誌められた。次に $20 \mathrm{~atm} に$ に加 任したまま放置したところ，約 30 秒 経過したところで，IP9001，Baxter 内部からの水漏れ認めた。加圧器を分 解して調べると，压力計と回路をつな ぐ樹脂製のコネクター部分にひび割れ があり，同部から水漏れが起きていた。

【考察】前述したように，経皮的血管 形成術施行に際し, 加圧器の圧力計の 值の持つ意味恃大きい。圧力計の誤差 が大きいことは，合併症の危険を伴う のみならず，過去に行われた経皮的血 管形成術においても，バルーン拡張が 不適切であった可能性が示唆される。 今问㖕测した加压器のうち，アナログ 表示の3 種類には，ブルドン管式圧力 計が使用されていた。ブルドン管式圧 力計については, J I S B 7505
で, $0.5 \sim 3.0$ 級の 4つの規格が定 められている。もっとも誤差の大きい 3.0 級でも，使用城の許容差は 3.0 \%とされている. 加圧器には輸入品が

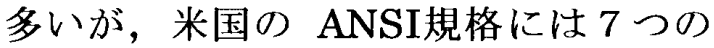
規格があり，最も誤差の大きいもので， 圧力計の中央 $1 / 2$ の目盛範囲で許容 差を $4 \%$ と規定している. 今回の結果 からは, 加圧器の中にはこれら規格を 大きく超える誝差を持つものがあり， 改善が必要と考えられた。

デジタル表示の Monarch25は，ス トレングージにより圧力を電気的に計 測している. $3 \sim 18$ atm の範囲で, 基準圧力に対する誤差は最大 $1.5 \%$ であった.デジタル表示ゆえに読み取 り誤差もなく，優れていると考えられ た。

【結論】バルーンカテーテル加圧器の 圧力計の精度について計測した。

J I S 規格を大きく超える誤差を持 つ加圧器があり，改善が必要と考えら れた。

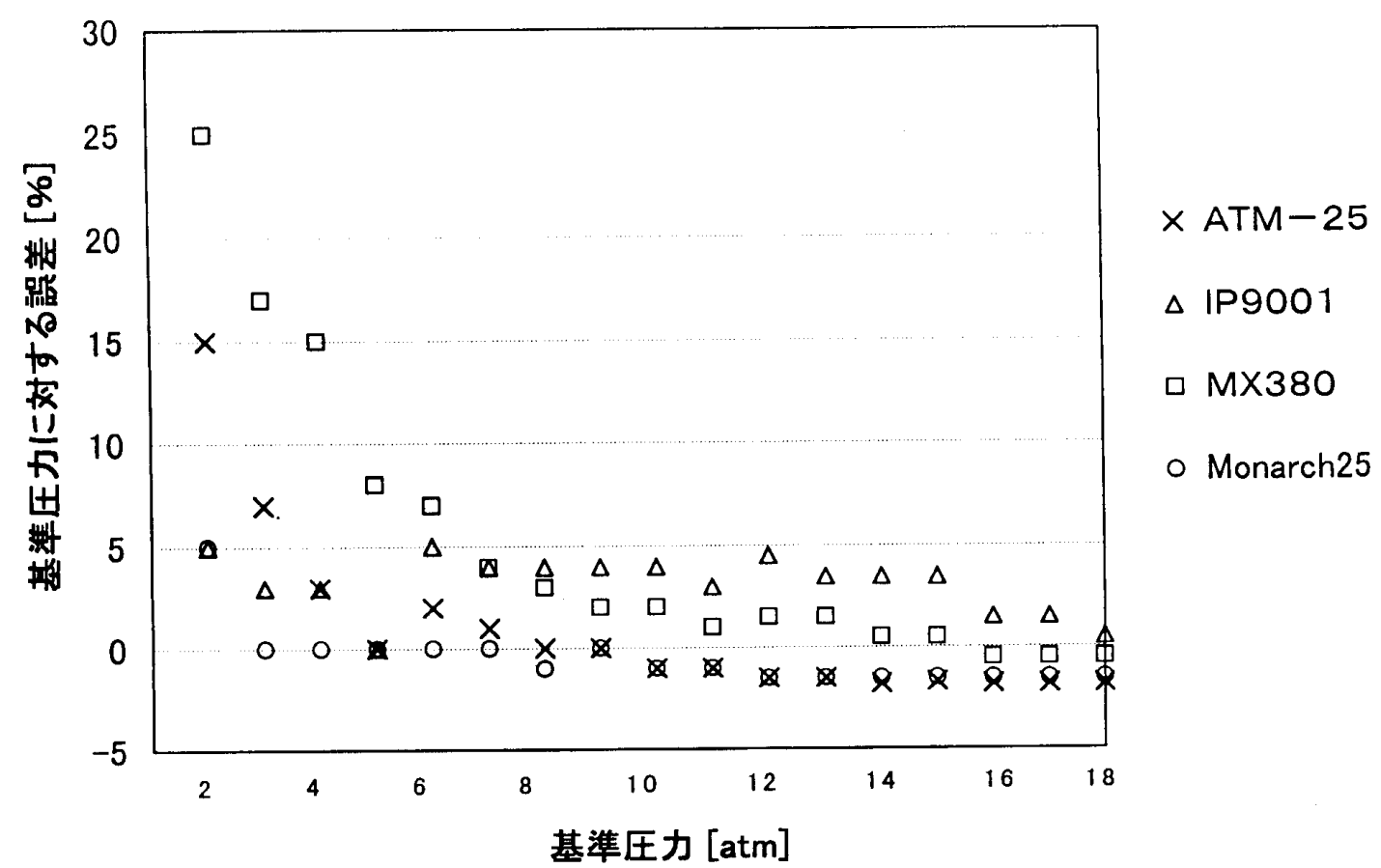

図2 各加压シリンジ圧力計の誤差 